\title{
THE INFLUENCE OF COMPETENCE ON EMPLOYEE PERFORMANCE: A STUDY ON THE DEPARTMENT OF POPULATION AND CIVIL REGISTRY IN KENDARI CITY, INDONESIA
}

\author{
Aminuddin*, Harmin Sitti, Asriani \\ Faculty of Social and Political Sciences, University of Halu Oleo, Indonesia \\ *E-mail: aminuddin fisip@yahoo.co.id
}

\begin{abstract}
This research was administered to: (1) analyze whether competence shared any influence on employee performance, (2) measure the influence of competence on employee performance in the Department of Population and Civil Registry in Kendari City. This study was expected to provide theoretical benefits for writers and readers in understanding the influence of competence on employee performance. Furthermore, this study also offered a practical benefit with its valuable insights for the betterment of policies made to improve the competences of employees in the Department of Population and Civil Registry. The population of this study included 85 employees from which 55 samples were selected, consisting of 43 civil servant employees and 12 honorary employees as operators. The data of this research were collected using questionnaires, observation and documentation. A statistical test in the form of simple regression analysis was employed to analyze the obtained data. Results of the regression test indicated that competence simultaneously showed a positive and significant influence of $73.00 \%$ on employee performance in the Department of Population and Civil Registry in Kendari City. Meanwhile, the remaining 27\% was influenced by other factors. Therefore, it can be inferred from the results that employee performance was enhanced if the competence was improved.
\end{abstract}

\section{KEY WORDS}

Competence, employee, performance, population, public service.

Civil Servants (PNS) serve as the state apparatus element responsible for providing public services in a professional, honest, fair, and equitable manner in the organization of the state, government and development duties.

The work productivity of civil servants in carrying out their functions is related to their competences. Therefore, organizations need to systematically make efforts of competence development. Competence development can be done through coaching and improvement of work competence and motivation possessed. Work competence is improved by upgrading aspects underlying the element.

Improving the bureaucracy performance in providing public services becomes an increasingly important issue to immediately get noticed by all parties. A bureaucracy with poor public service performance will greatly affect government performance in improving the state competitiveness in the global era. The performance of the public sector in Indonesia specifically still receives a lot of criticism. The people's expectation of a cleaner, more transparent and accountable governance has not been well realized. Corruption, Collusion and Nepotism practices are still widely found in the process of governance and public services. In fact, Corruption, Collusion and Nepotism practices have extended in scale and the perpetrators have worsened the performance of the public sector (Dwiyanto, 2006:52).

Demands of public services will always increase in terms of both quality and quantity along with the increase in population, community welfare, and environmental changes. To meet the demands needs more readiness and improvement in the apparatus performance so that there is no gap between the people's demands or expectations and the apparatus competences in carrying out their duties and functions. To reduce even eliminate the gap, the government bureaucracy must have high competences and continuously follow developments in the community. Besides, to anticipate such conditions, the government 
bureaucracy must be systematically prepared by creating a good and integrated apparatus institutional system, personnel system and governance mechanism so that the government bureaucracy is able and ready to face the increasing people's demands of public services.

One important issue often discussed internationally is related to demography as we often find in cases of immigration between countries. Deportation, detention, and even criminal cases are frequently underlain by citizenship status that is not completed with valid and official citizenship documents accordingly with the applicable standards in both the Republic of Indonesia and the international world.

The chaos of our population administration system has brought impacts in various fields, especially issues related to banking, economy, society, politics, and security in which there are often found double identities. Ironically, such double identities are mostly released by the same institution but different domiciles.

Law No. 24 of 2013 Article 68 states that civil registration certificates are civil annotations and records in the form of both citizenship identities and certificates while demographic events are events experienced by citizens that must be reported as it has implications to the issuance or change in the family card, identity card, and/ or other civil certificates including the moving, arrival, change of temporary residence address, and change from limited stay status to permanent stay status. In terms of civil registration, demographic events are vital events experienced by citizens regarding civil records, such as: (a) Birth Certificate, (b) Death Certificate, (c) Marriage Certificate, (d) Divorce Certificate, and (e) Child Recognition Certificate, and (f) Child Legitimization Certificate.

The Department of Population and Civil Registry of Kendari City as the official government institution authorized to carry out the administrative activities of the population and civil registry has sought to improve public services but there are still complaints and demands for repairs. Some of the complaints and demands are related to the lack of information about civil registration, double ID cards, convoluted rules, and the unavailability of demographic databases as a reference for the implementation of development programs including regional head elections. The lack of socialization from the implementing apparatuses is one of the causes of the non-optimal conditions of civil registry services to the public. Instead of actively participating in serving the public, the implementing apparatuses mostly tend to position themselves to wait for customers. Ultimately, many people are dissatisfied with the performance of the population and civil registry organization.

Moreover, Sinambela et al. (2010: 117) suggested that at least, there were 385 types of public services provided by the government apparatuses to the community, ranging from the making of birth certificates to death certificates. All the types of public services provided by both the central and regional government apparatuses to the community generally are still not satisfying. This is because the services provided are too complicated by reason that it is based on the defined procedures. Besides, it mostly takes a big amount of service costs and a very long service time, leading to ineffective and inefficient services.

. Several observation results have shown that there are still various weaknesses in civil services in Kendari City as follows: 1) the number of service apparatuses is still less compared to the people served, 2) the quantity and quality of facilities/ infrastructure supporting the services are insufficient, 3) the skills of service apparatuses are inadequate, seen from the delays in a number of daily duties related to public services, especially onlinebased services. Additionally, the frequent delays in the delivery of ID card-making forms from the Central Government cause the Civil Registry services in Kendari City to often accumulate and make the settlement process too late.

Seen from the ratio between the total population and the total underserved people, it is still far from the expectation. It can be reflected in the low output of services and the high number of unregistered vital demographic events occurring in the community. This is allegedly caused by the low performance of the Department of Population and Civil Registry in Kendari City.

Based on the background above, the statements of problems of this research are as follows: 
- Does competence has a significant effect on employee performance in the Department of Population and Civil Registry in Kendari City?

- How much is the effect of competence on employee performance in the Department of Population and Civil Registry in Kendari City?

Thus, the objectives of this research are as follows:

1) To describe whether competence affects employee performance in the Department of Population and Civil Registry in Kendari City.

2) To describe how much competence affect employee performance in the Department of Population and Civil Registry in Kendari City.

This research benefits theoretically and practically as follows:

- Theoretically, this research is expected to contribute to the theoretical improvement of human resource development, particularly the development of the concept of government apparatus competence and performance as well as regional government management;

- Practically, this research is expected to provide input for perfecting the policies of Kendari City Government, particularly the Department of Population and Civil Registry regarding the competence improvement of the City Government apparatuses/ officials so as to enhance their performance of public services.

\section{LITERATURE REVIEW}

The Concept of Competence. There are two terms deriving from two different schools about the concept of conformity in work. The terms are "Competency", which is a description of behaviors, and "Competence", which is a description of a task or the result of work (Palan, 2007: 5).

Although the difference between the two terms is generally accepted, the use of both terms is still frequently exchanged, causing everyone to have different meanings. According to Wibowo (2011: 325), competence is an ability to carry out a job or task based on skills and knowledge supported by work attitudes required for the job.

According to Spencer and Spencer in Sutrisno (2011: 207), the components of competence, including motives, traits, self-concepts, knowledge and skills, will affect performance.

Furthermore, Spencer and Spencer in Palan (2007: 6) outlined five characteristics forming competence as follows:

- Knowledge, referring to information and learning outcomes;

- Skills, referring to one's ability to carry out an activity;

- Self-concepts and values, referring to one's attitudes, values and self-image, such as one's belief that he can succeed in a situation;

- Traits, referring to physical characteristics and consistency of responses to situations or information, such as self-control and the ability to remain calm under pressure;

- Motives, referring to emotions, desires, psychological needs or other impulses driving actions.

Based on Government Regulation No. 100 of 2000, civil servant competence the ability and characteristics possessed by civil servants, including knowledge, skills, behaviors and/ or attitudes required in carrying out the duties. includes:

Covey, Roger and Merrill in Mangkunegara (2005:112) explained that competence

- Technical competence: knowledge and skills to achieve agreed goals and the ability to think of problems and seek new alternatives;

- Conceptual competence: the ability to see a large image to test various assumptions and change perspectives;

- Competence of interdependence effectively with others, including the ability to listen, communicate, get a third alternative, create a win-win agreement, try to reach a third alternative solution, operate effectively in an organization as a whole. 
Purwanto (2006: 8) asserted that competence is a capability required in carrying out a position. Competence is usually associated with expertise, skills, professionalism or functional jobs. State or political functional competence is far different from structural competence. The difference is in the main tasks, authority functions and responsibilities between one another.

From all the above arguments, the independent variable used in this research is competence, covering 5 (five) dimensions, namely (1) motives, (2) traits, (3) self-concepts, (4) knowledge, and (5) skills.

The Concept of Employee Performance. Performance is an often-used term in the management of organizations, both private, public, and government organizations. Mardiasmo (2005: 121) stated that performance is an important concept in a good and responsible governance. According to Simanjutak (2005: 1), performance is the achievement level of the implementation of certain tasks. Performance measurement is highly important to assess organizational accountability in producing better public services.

On the other side, Osborne and Gaebler in Keban (2010:1) revealed that performance appraisal or evaluation is an important key for the improvement and progress of both institutions and individuals. The only way to determine whether an institution or individual has succeeded in achieving the goal is by evaluating the performance of the institution or individual. From the evaluation results, it can be determined the types and levels of the incentives to be proposed or given.

Meanwhile, Rivai and Basri (2005: 14) argued that performance is a person's result or level as a whole during a certain period in carrying out his tasks compared to the likelihood results such as work standards, targets or criteria determined and mutually agreed in advance. Moreover, Sedarmayanti (2005: 51) explained that performance includes five aspects, namely: (1) quality of work, (2) promptness, (3) initiative, (4) capability, and (5) communication. The five aspects can be used as a measure in determining individual and organizational performance levels.

According to Mangkunegara (2005: 9), performance is work results achieved by someone in carrying out his function, covering work quality, work productivity, initiative, cooperation and responsibility. Furthermore, Simamora (2003: 416) described that in terms of performance, there are three aspects that are interrelated and needed to be understood by each employee or leader of a work unit or organization, namely (1) the description of jobs or tasks to be performed; (2) the expected results or goals of the jobs or functions; and (3) the required time to complete the jobs as expected.

From the review of literature above, the indicators used to measure the employee performance variable include (1) work quality, (2) work quantity, (3) initiative, (4) cooperation, and (5) responsibility.

Competence and Performance of Employee. Performance is a multi-dimensional construct covering many influencing factors. According to Palan (2007: 25), several experts have argued that one's competence will generate performance by a formula that Competence $=$ Performance .

Gibson in Moeheriono (2012: 66) described that there are three factors influencing one's performance, namely:

- Individual factors, including ability/ skill, family background, experience, and social and demographic levels;

- Psychological factors, including perception, role, attitude, personality, motivation and job satisfaction;

- Organizational factors, including organizational structure, job design, leadership, and reward system.

Mahmudi (2013: 20) explained that in the traditional system of performance appraisal, performance is only associated with personal factors. However, in reality, performance is often caused by other factors beyond personal factors, such as systems, situations, leadership or teams.

Meanwhile, according to Ruky in Sutrisno (2011: 209), competence consists of a number of key behaviors required to carry out certain roles to produce satisfactory work 
performance. The behaviors are usually showed consistently by employees carrying out their work activities. Behaviors without an intention or purpose cannot be defined as competence.

Sutrisno and Edi (2011) depicted the relationship between Competence and Performance as follows:

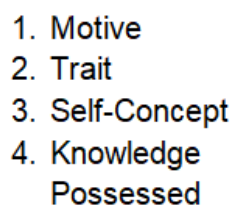

Figure 1 - Relationship between competence and performance
Result

Work

Performance

According to Clelland in Sedarmayanti (2012: 283), competence is a person's fundamental characteristics that have a direct influence on or can predict excellent performance. Spencer and Spencer in Palan (2007: 13) said that to be a superior performer in the workplace, one must have competence referring to the characteristics underlying his behaviors, consisting of motives, traits, self-concepts, knowledge, and skills that will affect his performance. If employee competence is good, his performance will be good too.

Thinking Framework. The thinking framework of this research illustrates that competence affects the quality of public services as depicted in the following chart:

\begin{tabular}{|c|c|}
\hline $\begin{array}{l}\text { Competence } \\
-\quad \text { Motive } \\
-\quad \text { Trait } \\
-\quad \text { Self-Concept } \\
-\quad \text { Knowledge } \\
-\quad \text { Skill } \\
\text { Spencer and Spencer in Sutrisno } \\
\text { (2011: 207) }\end{array}$ & $\begin{array}{ll}\text { Employee Performance } \\
\text { - } \quad \text { Work Quality } \\
-\quad \text { Work Quantity } \\
-\quad \text { Initiative } \\
-\quad \text { Cooperation } \\
\text { - } \quad \text { Responsibility } \\
\text { Mangkunegara (2005:9) and } \\
\text { Simamora (2003:416) }\end{array}$ \\
\hline
\end{tabular}

Figure 2 - Thinking Framework

Hypothesis. It is assumed that Competence significantly influences Employee Performance in the Department of Population and Civil Registry of Kendari City.

\section{METHODS OF RESEARCH}

The population of this research was all employees working in the Department of Population and Civil Registry of Kendari City in 2018 which amounted to 85 people distributed to 2 divisions, 1 secretariat and 10 Technical Implementation Units (UPTs) in 11 districts of Kendari City.

The sampling in this research was done intentionally by involving 55 employees, consisting of 43 civil servant employees and 12 honorary employees as operators spread over 10 Technical Implementation Units (UPTs) in 11 districts of Kendari City.

To obtain the data required in this research, the researchers used several techniques as follows:

1. Questionnaire: giving a list of questions to the respondents (employees) of the Department of Population and Civil Registry in Kendari City;

2. Documentation: recording data directly from documents related to the research problems;

3. Observation: observing directly the duty implementation of employees within the scope of the Department of Population and Civil Registry in Kendari City. 
The data in this research were analyzed using a simple linear regression analysis method with a computer application program namely SPSS (Statistical Product Service and Solution) Version 20 (Santosa and Ashari, 2013). Besides, an inferential statistical analysis was performed using a simple linear regression analysis method (Sudjana, 2013: 324) with the following equation model:

$$
Y=a+b x+e
$$

Where: $\mathrm{Y}=$ Competence of Government Apparatus; $\mathrm{X}=$ Employee Performance; $a=$ Constant Number; $b=$ Regression Coefficient; $\mathrm{e}=$ Error Level/ Interference Factor.

The hypothesis in this research was tested using a t-test. T-test aims to determine the effect of independent variables (partial) on the dependent variable. This test was done by observing the $t_{\text {count }}$ at $95 \%$ confidence level $(\alpha=0,05)$ with the degree of freedom (df) of $n-k-1$ where $n$ is the number of observations and $k$ is the number of independent variables.

The criteria for testing the hypotheses are as follows:

- If the $t_{\text {count }}>t_{\text {table }}, H_{1}$ is accepted, $H_{0}$ is rejected;

- If the $t_{\text {count }}<t_{\text {table }}, H_{1}$ is rejected, $H_{0}$ is accepted.

\section{RESULTS AND DISCUSSION}

Description of the Department of Population and Civil Registry in Kendari City. The Department of Population and Civil Registry in Kendari City is one of the institutions under the control of the Mayor of Kendari City in charge of providing population and civil registration in Kendari City. The number of employees in the Department of Population and Civil Registry of Kendari City was 85 people consisting of 43 civil servant employees and 42 honorary employees.

The Department of Population and Civil Registry of Kendari City serves 11 districts consisting of 65 sub-districts. The population of Kendari City in 2006 amounted to 244,586 people, increasing to 251,477 in 2007 and 334,335 in 2017 (Department of Population and Civil Registry ofKendari City, 2018). Growth in the population of Kendari City is expected to increase by $0.97 \%$ per year. The high population growth in Kendari City demands the capability of the Department of Population and Civil Registry of Kendari City to provide better public services.

Education Level-Based Respondent Characteristics. The level of education in this research is the level of last education possessed by the respondents. Education levels greatly influence in providing perceptions and judgements of questions, distinguishing a person's way of thinking in response to various problems faced.

Education levels of the respondents can be seen in Table 1 below:

Table 1 - Education Level-Based Respondent Characteristics

\begin{tabular}{|c|c|c|c|}
\hline No. & Education Level & Number of People & Percentage \\
\hline 1. & Senior High School (SMA) & 9 & 16.36 \\
\hline 2. & Associate Degree (D3) & 1 & 1.82 \\
\hline 3. & Bachelor Degree (S1) & 39 & 70.91 \\
\hline 4. & Master Degree (S2) & 55 & 10.91 \\
\hline \multicolumn{2}{|r}{} & Total & 100 \\
\hline
\end{tabular}

The table above shows that majority of the respondents, amounted to 39 people $(70.91 \%)$, possessed the bachelor degree (S1) education level. The other 9 respondents $(16.36 \%)$ was lastly graduated from Senior High Schools (SMA), followed by 6 respondents $(10.91 \%)$ with a master degree (S2) and 1 respondent $(1.82 \%)$ with an associate degree (D3). That is, the education levels of the respondents are relatively high, thus it can be predicted that they have sufficient basic thinking skills to plan and carry out work as well as solve various problems encountered. 
Working Period-Based Respondent Characteristics. The working period of an employee refers to the employee's working experience in a particular institution. The working period of the respondents can be seen in Table 2 below:

Table 2 - Working Period-Based Respondent Characteristics

\begin{tabular}{|c|c|c|c|}
\hline No. & Working Period (Years) & Number of People & Percentage \\
\hline 1. & $1-9$ & 7 & 12.73 \\
\hline 2. & $10-25$ and above & 48 & 87.27 \\
\hline \multicolumn{2}{|c|}{ Total } & 55 & 100 \\
\hline
\end{tabular}

Based on the table above, the majority of the respondents, which amounted to 48 people (87.27\%), have worked for $10-25$ years and above in the Department of Population and Civil Registry of Kendari City while the rest 7 respondents $(12.73 \%)$ have worked there for 1-9 years. It means that the working periods of employees of the Department of Population and Civil Registry of Kendari City are relatively long, thus it can be predicted that they have adequate experience to carry out their duties.

\section{RESULTS OF STUDY}

Regression Analysis Results. As described above, a simple linear regression analysis was done to answer the problems and hypothesis proposed in this research regarding the simultaneous effect of the independent variable on the dependent variable.

In summary, the results of the simple linear regression analysis are presented in the following table.

Table 3 - Results of the simple linear regression analysis

\begin{tabular}{|c|c|c|c|c|c|c|c|}
\hline \multicolumn{3}{|c|}{ Research Variables } & \multirow{2}{*}{$\begin{array}{l}\begin{array}{l}\text { Unstandardized } \\
\text { Coefficient } \\
(\beta)\end{array} \\
3.669 \\
0.082 \\
\end{array}$} & \multirow{2}{*}{$\begin{array}{l}t_{\text {count }} \\
2.739 \\
11.966 \\
\end{array}$} & \multirow{2}{*}{$\begin{array}{l}\text { Sig } \\
0.008 \\
0.000 \\
\end{array}$} & \multirow{2}{*}{$\begin{array}{l}\text { Alpha } \\
(5 \%)\end{array}$} & \multirow{2}{*}{$\begin{array}{l}\text { Result } \\
\text { Significant }\end{array}$} \\
\hline $\begin{array}{l}\text { (Constant) } \\
\text { Competence }\end{array}$ & $\rightarrow$ & $\begin{array}{l}\text { Employee } \\
\text { Performance }\end{array}$ & & & & & \\
\hline \multicolumn{8}{|c|}{$\begin{array}{l}\text { F-hitung }=143.184 \\
\text { Sig.F }=0.000\end{array}$} \\
\hline
\end{tabular}

Source : Processed Data Using SPSS Version 20.

Based on the computerized data processed using SPSS Version 20 in the table above, it can be obtained the following regression equation:

$$
Y=3.669+0,082
$$

The regression equation above can be explained as follows: $b_{0}=3.669$ reflects that the competence variable affected employee performance by $3.669 \% ; b_{1}=0,082$ reflects that if an increase in the competence variable by one unit was followed by an increase in employee performance by $0.082 \%$.

Table 4 - Determination Coefficient $\left(R^{2}\right)$

\begin{tabular}{|c|c|c|c|c|}
\hline Model & $\mathrm{R}$ & $\mathrm{R}$ Square & Adjusted R Square & Std. Error of the Estimate \\
\hline 1 & 0.854 & 0.730 & 0.725 & 1.33852 \\
\hline
\end{tabular}

Source: Processed Data Using SPSS Version 20.

The data processing analysis of the effect of the competence variable on employee performance in the Department of Population and Civil Registry of Kendari City showed an 
R-value of 0.854 . That is, the competence variable was closely and positively correlated with employee performance because the correlation coefficient was close to +1 .

Meanwhile, the effect of the competence variable $(X)$ on the employee performance variable $(Y)$ shown by the $R$-square $\left(R^{2}\right)$ reached 0.730 . It means that $73.0 \%$ of the employee performance was affected by their competence while the remaining $27 \%$ was affected by other factors outside this research focus.

$T$-Test. This test aimed to determine whether the competence variable $(X)$ partially had a positive effect on the employee performance variable $(Y)$ based on the regression results presented in the table above. The t-test was done by comparing the $t_{\text {count }}$ value with the $t_{\text {table }}$ value. From the comparison, it was concluded that if the $t_{\text {count }}>$ the $t_{\text {table, }}$, the competence variable $(X)$ significantly affected the employee performance variable $(Y)$. Vice versa, if the $t_{\text {count }}<$ the $t_{\text {table, }}$, the competence variable $(X)$ significantly affected the employee performance variable $(\mathrm{Y})$.

Table 5 - T-Test Results

\begin{tabular}{|c|c|c|c|}
\hline Variable & $\mathrm{T}_{\text {count }}$ & Sig & $t_{\text {table }}$ \\
\hline Competence $(\mathrm{X})$ & 11.966 & 0.000 & 2.006 \\
\hline
\end{tabular}

Source: Processed Data Using SPSS Version 20.

Based on the statistical partial test (t-test) of each variable as presented in the table above, the regression coefficient test of the competence variable $(X)$ showed a $t_{\text {count }}$ of 11.966 while the $t_{\text {table }}$ at $5 \%$ distribution was 2.006 . That is, the $t_{\text {count }}(11.966)$ was greater than the $t-$ table (2.006), indicating that there was a positive relationship between competence and employee performance.

From the t-test results above, it was concluded that the competence variable partially had an effect on employee performance. Thus, the hypothesis stating that Competence significantly influences Employee Performance was accepted.

\section{DISCUSSION OF RESULTS}

The discussion was made by looking at the empirical evidence from the hypothesis testing that had been conducted. It also includes the theories or empirical findings from the previous studies, either supporting or contradicting the results of the hypothesis testing conducted in this research.

The Effect of Competence on Employee Performance. The analysis results suggest that competence simultaneously had a positive and significant effect on employee performance in the Department of Population and Civil Registry of Kendari City, thus the research hypothesis was accepted. In other words, the competence variable simultaneously could explain the improvement of employee performance in the institution.

The effect of the competence variable with its dimensions is explained as follows:

1. From the motive dimension, it can be explained that employees in the institution have demonstrated organizational awareness to improve their workability and spirit in carrying out their duties and functions. Besides, the leader of the institution, at any time, provides stimulation to arouse the subordinates' work passion, provide explanation/ information to them about their duty implementation so as to create a conducive work climate, and always tries not to discriminate treatments for subordinates. Besides, promotions are given accordingly with the employee work performance and the employee recruitments are done accordingly with the job requirements so that the employees can show their good performance.

Regarding this, Dharma in Sutrisno (2011: 209) revealed that competence always contains an intention and goal often driven by motives or traits leading to an action to obtain a result. The leader of the institution has tried to do both formal and personal approaches to subordinates to move their hearts for increasing their devotion to the organization but there are still employees who have not optimally shown their performance. 
2. The trait dimension refers to perceptions of civil servant attitudes and behavior in self-control and self-confidence, such as being honest and adroit in carrying out their duties. It indicates that employees in the institution have implemented the values of honesty and dexterity in working, automatically improving their performance in carrying out their duties and functions even though there are still employees who have not been able to adjust to their work environment as expected.

According to Thoha (1998: 186), human behavior is a function and interaction between an individual and his environment. An individual's behavior is formed through the process of interaction between himself and his environment. Each individual has different characteristics to be always carried when entering a certain environment such as a person or bureaucracy. These characteristics include personal trust, appreciations, needs, and experience. Likewise, people as individual environments have certain characteristics, namely regularity manifested in the hierarchical order, division of certain duties and functions, authorities and responsibilities. Employees of the Department of Population and Civil Registry in Kendari City have interacted well with the community in the process of serving. However, there are still a huge number of complaints due to the long and complex procedure from the Technical Implementation Unit to the district level. As a result, many people try to take shortcuts by making direct administration. Another problem which often occurs and slows up the service is the run out of the forms required for ID card handling.

3. The self-concept dimension refers to perceptions of the ability of civil servants to develop and build group collaboration and be job satisfaction-oriented. In principle, government organizations in carrying out the duties and responsibilities must be accountable so as not to create doubt for employees and communities who deal with government institutions. Whether or not the implementation of a task is considered good is highly dependant on the sense of responsibility of employees in completing their duties and how they do it. It is also inseparable from employee discipline which is expected to be the main parameter of organizational success. Regarding this, employees of the Department of Population and Civil Registry in Kendari City have reflected a consistent attitude and sense of responsibility in completing the work. However, there are still some who are less disciplined in carrying out their duties.

According to Prasetyo (1997: 1), performance is the result of work, a management process, or an organization as a whole which must be shown concretely and can be measured by predetermined standards or benchmarks.

4. The knowledge dimension refers to the knowledge of employees of the Department of Population and Civil Registry in Kendari City regarding the tasks, authorities, and information related to the execution of their duties. The education level qualifications of the employees, which are mostly bachelor degree and master degree, sufficiently support the insight and ways of thinking of the employees so as to improve their performance.

In principle, employee performance can run well as expected if it is supported by adequate knowledge of the main duties and functions. This is consistent with the view of Covey, Roger and Merrill dala Mangkunegara (2005: 112) stating that technical competence is knowledge and expertise to achieve agreed goals and the ability to think various problems arising and seek new alternatives to solve them.

Thus, knowledge needed by civil servants in carrying out their duties can be improved as well as possible so as to optimize their performance. That is, it is necessary to improve the method of carrying out the duties and responsibilities imposed on civil servants, including work standards and targets which are likely to be achieved as expected by the government and society. Employees of the Department of Population and Civil Registry in Kendari City have the ability to interpret the concept formulated by the leaders (integrating policies) as well as gathering information from members of the organization and processing it into policy recommendations to be used as the leader's guidelines in making policies. Besides, they also have sufficient knowledge to complete their various tasks of any duties, are able to work hard, solve problems arising in the field effectively, and performing complex tasks. On another side, the work environment can encourage them to learn and improve knowledge about new work processes so as to generate better performance. Nevertheless, there are 
still employees who just work after being commanded and most of them are still limited in knowledge of their work.

5. The skill dimension refers to perceptions of the ability of civil servants to carry out their duties with high performance, often viewed from various criteria.

According to Hamalik (2005: 17), the skill aspect is based on the following criteria: (1) knowledge skill, namely decision making, problem solving and logical thinking, (2) psychomotor skill, referring to the skill to perform physical actions, (3) reactive skill, referring to habitual attitudes and self-awareness, (4) interactive skill, which is acting in interaction with other people (including both physical elements and thinking activities).

Regarding this, employees of the Department of Population and Civil Registry in Kendari City have participated in various training related to their duties although the number is still limited. The research results indicate that the employees have been increasingly skilled to do their tasks even though they are not yet maximal. However, overall, they have been able to support the process of carrying out the duties related to population and civil registration in Kendari City. This is in line with Atmosoeprapto (2001: 52) stating that competence comes from formal education, graded education and training, and functional training.

Employee participation in education and training programs is basically an effort for employee development in terms of knowledge and skills. It is highly effective in shaping employee attitudes. In this regard, an employee in carrying his tasks should notice work dimensions that can affect his performance.

Kendari City Government has made maximum efforts to develop human resources based on technology although it is still not evenly distributed and its application has not been optimal. It is strongly related to competence-based management of apparatus human resources which is expected to lead to recruitment, selection, development, performance management, career management, and compensation. Adequate employee competence, in turn, can produce a high performance that is indispensable in current regional government organizations.

\section{CONCLUSION}

Competence simultaneously influences the performance of employees in the Department of Population and Civil Registry viewed from the three dimensions as follows:

- Motive dimension, in which employees have work competence and spirit so as to increase their performance;

- Trait dimension, in which employees are honest and adroit in working and this positively affects their performance;

- Self-concept dimension, in which employees have the sense of responsibility in serving the community, automatically improving their performance;

- Knowledge dimension, in which majority of employees have the education level qualifications of bachelor degree and master degree, meaning that they have sufficient insight and way of thinking so as to improve their performance;

- Skill dimension, in which there have been various training participated by employees although the number is still limited, leading to increased job mastery and performance improvement.

Based on the regression test, competence significantly influences the performance of employees in the Department of Population and Civil Registry of Kendari City. That is, the higher the employee's competence value is, the better the employee's performance will be.

The results of the determination coefficient analysis indicate that competence had a significant effect of $73.00 \%$ on the performance of employees in the Department of Population and Civil Registry of Kendari City while the remaining $27.00 \%$ was influenced by other factors. 


\section{SUGGESTIONS}

It is necessary to increase the competence of employees of the Department of Population and Civil Registry in Kendari City, hold training according to the employee main duties and functions so as to improve their performance.

It is necessary to improve supporting facilities and infrastructure for employees so as to improve their performance in serving the community.

Future researchers are expected to further emphasize and deepen the study of the influence of competence on employee performance by adding other dimensions outside this research focus. Besides, it is necessary to add samples to examine other factors influencing employee performance in addition to the competence variable.

\section{REFERENCES}

1. Atmosoeprapto, K. 2001, Produktivitas: Aktualisasi Budaya Perusahaan. Jakarta: PT. Elex Mediakomputindo.

2. Dwiyanto, A., Partini, R., Wicaksono, B. 2002. Reformasi Birokrasi Publik di Indonesia. Yogyakarta: Pusat Studi Kependudukan dan Kebijakan Universitas Gajah Mada.

3. Hamalik, O. 2005. Pengembangan Sumber Daya Manusia (Manajemen Pelatihan Ketenagakerjaan) Pendekatan Terpadu. Jakarta: Bumi Aksara.

4. Keban, Y.T. 2010. Isu Pengembangan Kapasitas dan Good Governance Dalam Reformasi Birokrasi Aparatur Negara Ditinjau Kembali. Yogyakarta: Penerbit Gava Merdia.

5. Mahmudi, 2013. Manajemen Kinerja Sektor Publik. Yogyakarta: YKPN.

6. Mangkunegara, A.A.A.P. 2015. Evaluasi Kinerja SDM. Bandung: Refika Aditama.

7. Mardiasmo, 2005. Akuntansi Sektor Publik. Yogyakarta: Penerbit Andi.

8. Moeheriono, 2012. Perencanaan, Aplikasi dan Pengembangan Indikator Kinerja Utama (IKU) Bisnis dan Publik, Jakarta: RajaGrafindo Persada.

9. Moenir, H.A.S. 2003, Manajemen Pelayanan Umum di Indonesia. Jakarta: Bumi Aksara.

10. Palan, R. 2007. Competency Management, Teknik Mengimplementasikan Manajemen SDM Berbasis Kompetensi Untuk Meningkatkan Daya Saing Organisasi. Translated by O.M. Jalal. Jakarta: Penerbit PPM.

11. Prasetyo, I. 1997. Analisis Kinerja: Panduan Praktis Untuk Menganalisis Kinerja Organisasi, Kinerja Prosedur dan Kinerja Pegawai. Jakarta: LAN.

12. Ridwan \& Akdon, 2007, Rumus dan Data Dalam Analisis Statistika Untuk Penelitian (Administrasi Pendidikan-Bisnis-Pemerintahan-SosialKebijakan-Ekonomi-HukumManajemen-Kesehatan). Bandung: Alfabeta.

13. Rivai, V. \& Basri, A.F.M. 2005. Performance Appraisal. Jakarta: PT. Raja Grafindo Persada.

14. Santosa, P.B. \& Ashari. 2005. Analisis Statistik Dengan Microsof Exceldan SPSS. Yogyakarta: Andi.

15. Sinambela, L.P., Syaefuddin, Ghazaki, R. 2010. Reformasi Pelayanan Publik. Jakarta: PT. Bumi Aksara.

16. Sedarmayanti. 2001. Sumber Daya Manusia dan Produktivitas Kerja. Bandung: Mandar Maju.

17. Simamora, H. 2004. Manajemen Sumber Daya Manusia (Edisi Revisi). Yogyakarta: STIE YPKN.

18. Simanjuntak, P.J. 2005. Manajemen dan Evaluasi Kinerja. Jakarta: FE UI.

19. Sugiyono. 2001, Metode Penelitian Administrasi. Bandung: Alfabeta.

20. Sudjana, 2013, Tehnik Analisis Data Kualitatif. Bandung: Tarsito.

21. Supriady, 2002. Otonomi Penyelenggaraan Pemerintahan Daerah. Jakarta: PT.Gramedia Pustaka Utama.

22. Sutrisno, E. 2011. Manajemen Sumber Daya Manusia, Jakarta: Kencana.

23. Thoha, M. 1998, Perilaku Organisasi. Jakarta: PT.Rajawali.

24. Wibowo, 2013, Manajemen Kinerja. Jakarta: PT. Raja Grafindo Persada. 